\title{
The Relationship between Extraversion and Boundaryless Career Attitudes on Millennial Employees
}

\author{
Karina Amalia, Eka Gatari, ${ }^{1,2}$ \\ ${ }^{1,2}$ Faculty of Psychology, University of Indonesia, Depok, Indonesia \\ E-mail: eka.gatari31@ui.ac.id
}

\begin{abstract}
This study was conducted to examine the relationship between extraversion with the dimensions of boundaryless career attitudes, boundaryless mindset and organizational mobility preferences on Millennial employees. This is a correlational study that used the survey as the data gathering method. Extraversion was measured using the short version of IPIP (1999), while boundaryless mindset and organizational mobility preferences were measured using BCAS (2006). Total participant of this study was 196 millennial's generation employees. Results indicated that extraversion was positively related to boundaryless mindset, but not organizational mobility preferences on Millennial's employees. This result implied that organizations should consider including extroverted Millennial employees in inter-department and inter-organizations projects to make them more comfortable and satisfied with their jobs.
\end{abstract}

Keywords: boundaryless career orientation; boundaryless mindset; extraversion; Millennials; organizational mobility preferences

\section{Introduction}

Moving from one company to another in a relatively short time, or "job hopping," has become a familiar concept to some employees ("Kutu Loncat' Tak Banyak Diminati Perusahaan", 2013). Job hopping is more likely to be found among younger employees ("Survei Membuktikan: 60 Persen Anak Muda Indonesia Suka Berpindah Tempat Kerja", 2013), or in these days, found among the Millennials. The Millennials, or Generation Y, are those born between 1980 and 1995 (Hays, 2014), and began to enter the world of work in late 1999 and 2000s (Lyons, Schweitzer, Ng, \& Kuron, 2012). A survey conducted by JobStreet.com on 3,500 respondents in Indonesia showed that $67 \%$ of Millennial employees tend to move to work in less than one year (Ningrum, 2016). Study results by Lyons et al. (2012) in Canada that compared the displacement of work done by the generation of Baby Boomers, Generation X, and Millennials when the age of individuals in the generation stepped on 20-30 years also found that Millennials had the highest rate of job movement, compared to previous generations. Furthermore, Martin (2005) also explained that the Millennial Generation was known to be interested in finding flexible jobs, which can make him move well from projects, positions, departments and job sites.

Based on data obtained from BPS (Badan Pusat Statistik [Central Bureau of Statistics]) survey in Indonesia, 84 million Millenials were entering the workforce, which was $50 \%$ of the productive age population (Wulan \& Ninik, 2017). As a generation that would soon master various positions within the company, this generation can certainly endanger the company if they kept switching jobs. Companies also needed to be aware of Millennials that were seeking more flexible jobs and would resign if they did not have their preferences met.

We believed that this phenomenon was an indication of a career shift that had been mentioned by previous research. Eby, Butts, and Lockwood (2003) stated that nowadays, employees were not expecting that they would have a lifetime job with one company. Arthur (1994) mentioned that there were changes in career orientation, in which employees move from a career that was bound to a particular organization to a career that can be pursued within several organizations. The shift from traditional career orientation to a 'new career' orientation was stated by Briscoe and Hall (2006) to be the emergence of 'boundaryless career' that is 
first coined by Arthur (1994, p. 296). Individuals with boundaryless career attitudes were described as someone who would comfortable and enthusiastic in creating and maintaining the relationship with other organizations outside his / her current organizational boundaries (Briscoe et al., 2006).

Boundaryless career attitudes can be explained by looking at both psychological and physical mobility (Sullivan \& Arthur, 2006). Briscoe, Hall, and DeMuth (2006) referred to psychological mobility as boundaryless mindset (BM), and physical mobility as organizational mobility preference (OMP). Both of them are the dimensions of boundaryless career attitudes (Briscoe et al., 2006). Briscoe et al. further described individuals with BM had a general attitude or desire to work beyond organizational limits or work with others outside their company. In order to work with various companies, individuals with BM still rely on one company or the company they were working on at that time (Briscoe et al., 2006). In other word, individuals with high BM sought an organization or position that enable them to meet and work with people from other organizations or departments. The phenomenon stated by Martin (2005), which showed that Millennials were looking for more flexible jobs, also fit the description of individuals with high BM.

On the other hand, individuals with high OMP tended to move to different companies (Briscoe et al., 2006). The movement made by individuals with high OMP include actual mobility between occupation, position, and state (Sullivan \& Arthur, 2006). Individuals with high OMP would be more comfortable, and might even prefer, pursuing a career by moving from one organization to other organizations (Briscoe et al., 2006). This career orientation can be a perfect explanation why a lot of Millennial employees tend to do job hopping.

To further emphasize its importance, the emergence of this new career orientation had found to have an impact on companies. Inkson, Gunz, Ganesh, and Roper (2012) found boundaryless career attitudes can affect turnover rates in companies. Employees with boundaryless career orientation would be more active regarding their career and would be open to various job opportunities (Lips-Wiersma \& Mcmorland, 2006).

With those in mind, it was not surprising that researchers try to find variables linked to boundaryless career attitudes. Some researchers argued that demographic factors such as gender, age, educational level, and cultural differences might predict boundaryless career attitudes (Segak et al., 2014; Segers, Inceoglu, Vloeberghs, Bartram, \& Henderickx, 2008; Sullivan \& Arthur, 2006). Effects of behavioral traits or behavioral factors such as individual personality can also affect the appearance of boundaryless career attitudes (Briscoe et al., 2006; Kaspi-Baruch, 2015; Porter, Woo, \& Tak, 2015). Kaspi-Baruch (2015) mentioned that personality can primarily affect a person's career orientation since it would determine a person's perceptions and reactions to his / her environment, including his / her organization.

Previous research had found several personality traits related to boundaryless career orientation. Briscoe et al. (2006) found that personality such as proactive personality correlated with boundaryless career attitudes. In addition, mastery goals, career authenticity, and openness to experiences were found to have a positive relationship with boundaryless career attitudes. Kaspi-Baruch (2015) added that extraversion was positively associated with BM through learning goal orientation. Research from Porter et al. (2015), also found that extraversion and agreeableness had a relationship with BM.

Based on those results, there was no doubt that some personality traits were linked to boundaryless career attitudes. However, we proposed that Millennial employees have unique characteristics that might point to a particular personality trait that had a strong link with boundaryless career orientation. The understanding of whether the personality trait would have a stronger relationship when the research was conducted to Millennials can be the key to understand Millennials better. This study is expected to provide further understanding to the company in selecting and placing employees, especially employees of Millennial Generation.

In this research, we would like to focus on extraversion as the personality trait that is apparent in Millennials. This focus was reinforced by statements from Twenge and Campbell (as cited in Lyons et al., 2012) that of all the five traits in the big five personality model, extraversion is higher in Millennials. Lyons et al. (2012) further argued that extraversion is what makes individuals change their job. Therefore, we were interested in investigating the relationship between boundaryless career attitudes and extraversion in Millennials. 
Extraversion is "the dimension underlying a broad group of traits, including sociability, activity, and the tendency to experience positive emotions such as joy and pleasure" (Costa \& McCrae, 1992, p. 5). Individuals with high extraversion were also motivated to learn, which is one of the positive things in this personality (Mikael, Winberg, \& Hellgren as cited in Kaspi-Baruch, 2015). The characteristics of the individual with high extraversion are also in line with the explanation of individual with boundaryless career orientation from Arthur and Rousseau (1996), who stated that relationship with others, learning, and persistence were important characteristics in boundaryless career attitudes individuals.

As mentioned before, researchers have found a positive relationship between extraversion and boundaryless career attitudes (Kaspi-Baruch, 2015). However, there was no research in the author's knowledge that specifically targeted Millennial employees as the study sample. Considering that Millennial employees had different views and characteristics than employees from other generations, such as the higher level of extraversion (Twenge \& Campbell, as cited in Lyons et al., 2012), we might find different results. Furthermore, the study would cement whether the link between extraversion and boundaryless career orientation would hold true if conducted specifically with Millennial employees as the study sample.

The relationship between extraversion and boundaryless career attitudes in Millennial employees can be further explained using two dimensions of boundaryless career attitudes, BM and OMP. First of all, we would like to explain the relationship between extraversion and BM. Individuals with high BM tend to enjoy working with others outside of their organization (Volmer \& Spurk, 2011). This tendency matches the characteristics of extroverted individuals, who enjoy others' company (McCrae \& Costa, 1987), and would likely seek opportunities to connect with others.

With the need of Millennial employees to for a flexible job (Martin, 2005) and various work tasks (Berenguer et al., 2009; Lancaster \& Stillman, 2002; Lyons et al., 2012), this tendency can even be strongly translated to BM. Millennial employees with high extraversion and the need to have a flexible job might enjoy finding new friends outside of their current departments and organizations. With these new connections, they can ask for various opportunities to work with different departments and organizations. Based on this argument, we hypothesize that:

$\mathrm{H}_{1}$ : Extraversion is positively related to boundaryless mindset

Furthermore, individuals with high extraversion can have a vast network and tend not to attach themselves (Sutin, Costa, Miech \& Eaton, 2009). Millennial employees that had a lot of friends and acquaintances can have a better chance to have information on job opportunities, which would make them prone to get attracted to potential job opportunities. Porter et al. (2015) also stated that individuals with high extraversion had a positive outlook on their competence to seek a job alternative. The positive outlook would then make them easier to contemplate changing jobs, thus making them easier to have high OMP. Millennial employees who have extraversion, might even quicker in considering to change jobs since Millennials were not patient enough to wait for their career advancement (Ng, Schweitzer, \& Lyons, 2010). Based on these arguments, we hypothesize that:

$\mathrm{H}_{2}$ : Extraversion is positively related to organizational mobility preferences

\section{Methods}

Sample. Participants in this study are employees aged 22-37 years and have at least a one-year career experience. Participants in this study amounted to 131 employees from various organizations who completed the questionnaire online. There were more female participants $(56.5 \%)$ than male $(43,5 \%)$, participants that have a Bachelor degree $(82,4 \%)$, unmarried $(87,8 \%)$, is a staff $(61,1 \%)$, a permanent employee $(71,8 \%)$, had change companies less than 2 times during their career $(83,2 \%)$, and lasted < less than 2 years in the current organization $(77,9 \%)$.

Research Design. The design of this study was correlational, with data collection using survey. The correlation was analyzed using Pearson correlation.

Instrument and Measurement. This study used Boundaryless Career Attitudes Scale (BCAS) developed by Briscoe et al. (2006), to measure BM and OMP. BM was measured using eight items, while OMP was measured using five items. All of 
the items in OMP were reverse scored, while all of the items in BM were not reverse scored. Reverse scoring means that participants who responded with ' 1 ' were scored ' 5 '. On the other hand, BM items that were not reversed scored was scored according to the scale. This means that participants who responded with ' 1 ' was also scored ' 1 ' on the respective item. Participants were asked to respond whether the statements within both measurements appropriately described the participants using 5-point Likert scale $(1=$ very inappropriate; 5 = very appropriate). These anchor points were slightly different from the original scale by Briscoe et al. (2006). It was simplified from the original scale $(1=$ too little or no extent; $5=$ to a great extent) for better readability in Indonesian. Examples of BM items from Briscoe et al. (2006) were, "I enjoy working with people outside my organizations" and "I enjoy jobs that require me to interact with people in many different organizations." Examples of OMP items from Briscoe et al. (2006) were, "In my ideal career, I would work for only one organization" and "I prefer to stay in a company I am familiar with rather than look for employment elsewhere."

Extraversion was measured using the shortened version of IPIP, developed by Goldberg (1999). IPIP had ten items to measure extroversion, in which five of them were reversed scored. Participants were asked to indicate whether the statements accurately described them or not using 5-point Likert scale (1 = very inaccurate; $5=$ very accurate). Examples of the extraversion items were, "I make friends easily," and "I don't like to draw attention to myself." As with the BCAS, we made an adjustment to the translated items for better reliability. We have adapted all the measurements to the Indonesian language. We first translated the measurements into Indonesian, backtranslated the translation with the help of a person who speaks bilingual (Indonesian and English), and then we also discussed the translation with those we considered experts on the topic.

Procedure. This study uses questionnaires that were distributed online and made by Google Spreadsheet. The questionnaires have different sections, including a general explanation regarding the questionnaire's purpose and the researcher's contact, informed consent form, instructions on how to fill the questionnaire, and the variable measurements. In the general explanation, we also explained that the questionnaire is anonymous and participants' data would be analyzed aggregately as a group. Participants can stop filling the questionnaire if they were uncomfortable continuing it.
Once the questionnaires were ready, we tested the readability of the questionnaire. This readability test was conducted on three employees, with two of them giving opinions to offline questionnaires and one for the online questionnaires. We mostly asked about whether the items were easy to understand and respond, and asked for other suggestions regarding the questionnaires.

We then conducted a pilot study on 30 participants, which consisted of 12 participants that filled the questionnaire offline and 18 participants online. Cronbach's alpha coefficient obtained in a pilot study for BCAS is .90 for both BM and OMP scale, and .89 for the short version of IPIP. In addition, we also analyzed the items using corrected item-total correlation to ensure the internal validity of the items. We referred to a standard set by Nunally and Bernstein (1994), who stated that items with good internal validity should have $\mathrm{CR}_{\mathrm{it}}>.3$. All of the items passed the standard. The final process of this preparation phase was done to ensure that the measuring instruments used had good reliability and validity.

After the pilot test, we proceeded to the field study for three weeks from April 2-23, 2017. After deliberating on using an offline or online version of the measurement, we focused our data on questionnaires that were spread online due to limitations by the company.

\section{Results.}

After distributing the questionnaire link, researchers obtained 157 questionnaires online. However, we can only analyze 131 respondents because some of them did not fit the characteristics that we required (22-37 years and have at least a one-year career experience).

Table 1.

Correlation between BM, OMP, and Extraversion

\begin{tabular}{lcccc}
\hline Variable & M & SD & $\mathbf{1}$ & $\mathbf{2}$ \\
\hline 1. E & 3.32 & .70 & - & \\
2. BM & 3.94 & .72 & $.43^{* *}$ & - \\
3. OMP & 3.30 & .90 & .12 & -.01 \\
\hline * $\operatorname{sig} p<.05 ; * * \operatorname{sig} p<.01(1-$ tailed) & & \\
E = extraversion; BM = Boundaryless & mindset; OMP = \\
organizational mobility preferences &
\end{tabular}

Table 1 showed that there was a significant relationship between extraversion and $\mathrm{BM}(\mathrm{r}=.43, \mathrm{p}$ $<.01)$. This result demonstrated that high extraversion score would also mean that the 
individual has a high BM score. That is, when individuals had a great interest in social relationships, then the individual also had a high tendency to work in with people outside of his / her company. However, there is no significant relationship between extraversion and OMP $(\mathrm{r}=.12$, $\mathrm{p}>.05)$. Thus, extraversion only has a relationship with BM, but not OMP.Discussion \& Conclusion

Discussion. The main results of the study show that extraversion has a significant relationship with BM, but not with OMP. These results did not fully support previous research that found that extraversion was associated with BM and OMP (Kaspi-Baruch, 2015). This research supports that the relationship between extraversion and BM can also be found in Millennial employees, though there is an only moderate correlation with BM. This means that extraversion, which is said to be higher in Millennials (Twenge \& Campbell, as cited in Lyons et al., 2012), can foster BM in Millennials more than other generations. However, the moderate correlation between extraversion and BM shows that there might be other variables that can be related to $\mathrm{BM}$ more than extraversion. Deriving from the study by Briscoe et al. (2006) personality variables that we think merited more exploration is an openness to experience and mastery goal orientation. We suggested further research regarding this topic especially because Millennials values openness to change and self-enhancement (Lyons, Duxburry, \& Higgins, 2007), which is in line with openness to experience and mastery goal orientation respectively.

Even so, companies can consider this research result to pay more attention to the needs of extroverted Millennial employees to work outside organizational boundaries. The correlation between extraversion and $\mathrm{BM}$ shows that companies should consider giving inter-department and inter-organization projects to extroverted Millennial employees. Project opportunities and tasks that enable Millennial employees to work with people outside their companies can be a key to make talented Millennial employees more comfortable and satisfied with their jobs. This is important since Millenial employees might leave their jobs if they perceive they can get better opportunities (Twenge, 2010)

It seems that the tendency to connect with other people does not seem to be related to OMP. This means that those who have good networking does not necessarily have the tendency to change their organizations. We presumed that there might be a moderator that can affect the relationship between extraversion with OMP. We propose individual competence as the moderator that can strengthen the relationship between them. If a Millenial does not have the necessary competence, then the opportunities gained from their network cannot be fully utilized. This individual competence would make someone be more noticeable than the others. Competence is also needed so an individual can change his / her job (Gerli, Bonesso, \& Pizzi, 2015). Poor individual competence can mean low expectation to gain opportunities for a new job that will make it harder for an individual to tend to change organizations easily.

This research also has limitations. There was a lot of reduction in number due to nonconformity with the criteria that researchers have set, e.g., some participants were younger than 22 or older than 37 , and some of them had less than a year work experience. The amount of unusable data shows that there is a need to brief our contact with the company better. Even so, having 131 participants as our participants are also a hard enough feat to gain, and we hope that the relatively large sample means that it would support the accuracy of this research. Future research should also be aware of common method bias that might arise. It would be better if the next research used time lag method to avoid bias affecting the research results, such as bias that occurs when participants are trying to respond to questions in similar ways (Podsakoff, MacKenzie, Lee, \& Podsakoff, 2003).

Conclusions. Based on the analysis and interpretation of research results, it is known that there is a significant positive relationship between extraversion and boundaryless mindset, but not organizational mobility preferences. The result shows that Millennial employees that have high extraversion would also have high BM.

\section{References}

Arthur, M. B. (1994). The boundaryless career: A new perspective for organizational inquiry. Journal of Organizational Behavior, 15, 295-306. https://doi.org/10.1002/job.4030150402

Arthur, M, B. \& Rousseau, D, M. (1996). The boundaryless career: A new employment principle for a new organizational era. New York, NY: Oxford University Press.

Briscoe, J, P., \& Hall, D, T. (2006). The interplay of boundaryless and protean careers: Combinations and implications. Journal of Vocational Behavior, 69, 4-18. https://doi.org/10.1016/j.jvb.2005.09.002

Briscoe, J, P., Hall, D, T., DeMuth, R, L, F. (2006). Protean and boundaryless careers: An empirical exploration. Journal of Vocational Behavior, 69, 30-47. https://doi.org/10.1016/j.jvb.2005.09.003 
Çakmak-Otluoğlu, K, Ö. (2012). Protean and boundaryless career attitudes and organizational commitment: The effects of perceived supervisor support. Journal of $\begin{array}{lll}\text { Vocational Behavior, } & 80, & 30-47 .\end{array}$ https://doi.org/10.1016/j.jvb.2012.03.001

Clarke, M. (2009). Plodders, pragmatists, visionaries, and opportunists: Career patterns and employability. Journal of Career Development International, 14, 8 - 2 . https://doi.org/10.1108/13620430910933556

Costa, P, T., \& McCrae, R, R. (1992). Normal personality assessment in clinical practice: The NEO personality inventory. Psychological Assessment, 4, 5-13. doi: 10.1037/1040-3590.4.1.5. https://doi.org/10.1037/10403590.4.1.5

Eby, L, T., Butts, M., \& Lockwood, A. (2003). Predictors of success in the era of the boundaryless career. Journal of Organizational Behavior, 24, 689-708. https://doi.org/10.1002/job.214

Gerli, F., Bonesso, S., \& Pizzi, C. (2015). Boundaryless career and career success: The impact of emotional and social competencies. Frontiers in Psychology, 6, 1-17. https://doi.org/10.3389/fpsyg.2015.01304

Goldberg, L, R. (1999). A broad-brandwidth, public domain, personality inventory measuring the lower-level facets of several five-factor models. In Mervielde, I., Deary, F., De Fruyt., \& Ostendorf, F (Eds), Personality psychology in Europe (p. 7 - 28) Tilburg, The Netherlands: Tilburg University Press

Hays, D, W. (2014). Examining differences between Millennial and all employee levels of job satisfaction and importance and satisfaction with the immediate supervisor relationship. Journal of Managerial Studies and Research 2, 1-7.

Inkson, K., Gunz, H., Ganesh, S., Roper, J. (2012). Boundaryless careers: Bringing back boundaries. Organization Studies, $33, \quad 323-340$. https://doi.org/10.1177/0170840611435600

Kaspi-Baruch, O. (2015). Motivational orientation as a mediator in the relationship between personality and protean and boundaryless careers. European Management Journal, 34 182-192. https://doi.org/10.1016/j.emj.2015.10.004

'Kutu loncat' tak banyak diminati Perusahaan ['Job hoppers' did not attract companies much]. (2013, November 27). Retrieved from http://careernews.id/issues/view/2187Kutu-Loncat-Tak-Banyak-Diminati-Perusahaan

Lips-Wiersma, M., \& Mcmorland, J. (2006). Finding meaning and purpose in boundaryless careers: A framework for study and practice. Journal of Humanistic Psychology, 46, 147-167. https://doi.org/10.1177/0022167805283776

Lyons. S. T.. Duxburv. L.. \& Higgins. C. (2007). An empirical assessment of generational differences in basic human values. Psvchological Renorts. 101. 339-352. https://doi.org/10.2466/pr0.101.2.339-352

Lyons, S, T., Schweitzer, L., Ng, E, S, W., \& Kuron, L, K, J. (2012). Comparing apples to apples: A qualitative investigation of career mobility patterns across four generations. Career Development International, 17, 333357. https://doi.org/10.1108/13620431211255824
Martin, C, A. (2005). From high maintenance to high productivity. Journal of Industrial and Commercial Training, 37 39 https://doi.org/10.1108/00197850510699965

44

McCrae, R. R. \& Costa, P. T. (1987). Validation of the fivefactor model of personality across instruments and observers. Journal of Personality and Social Psychology, 52, 81-90. https://doi.org/10.1037//0022-3514.52.1.81

Ng, E, S, W., Schweitzer, L., \& Lyons, S, T. (2010). New generation, great expectations: A field study of the millennial generation. Journal of Business and Psychology, 25, 281- 292. https://doi.org/10.1007/s10869-010-9159-4

Ningrum, D, W. (2016, Desember 16). Mayoritas Generasi Milenial kutu loncat [The majority of Milennial Generation are job hoppers]. Dari http://tekno.liputan6.com/read/2679823/mayoritasgenerasi-milenial-kutu-loncat?source $=$ search

Podsakoff, P. M., MacKenzie, S.B., Lee. J., \& Podsakoff, N. (2003). Common method biases in behavioral research: A critical review of the literature and recommended remedies. Journal of Applied Psychology, 88, 879-903. https://doi.org/10.1037/0021-9010.88.5.879

Porter, C., Woo, E, S., \& Tak, J. (2015). Developing and validating short form protean and boundaryless career attitudes scale. Journal of Career Assesment, 24, 162-181. https://doi.org/10.1177/1069072714565775

Segers, J., Inceoglu, I., Vloeberghs, D., Bartram, D., Henderickx, E. P. (2008). Protean and boundaryless careers: A study on potential motivators. Journal of Vocational Behavior, $73, \quad 212-230$. https://doi.org/10.1016/j.jvb.2008.05.001

Sullivan, S, E., \& Arthur, M, B. (2006). The evolution of the boundaryless career concept: Examining physical and psychological mobility. Journal of Vocational Behavior, 69, 19-29. https://doi.org/10.1016/j.jvb.2005.09.001

Survei membuktikan: 60 persen anak muda Indonesia suka berpindah tempat kerja [Survey proves: 60 percent of Indonesian young adults like to change jobs]. (2013, September 27). Retrieved from http://www.tribunnews.com/lifestyle/2013/09/27/surveimembuktikan-60 persen-anak-muda-indonesia-suka-berpindah-tempat-kerja

Sutin, A. R., Costa, P. T., Miech, R., \& Eaton, W. W. (2009). Personality and career success: Concurrent and longitudinal relations. European Journal of Personality, 23, 71-84. https://doi.org/10.1002/per.704

Twenge. J. M. (2010). A review of the empirical evidence on generational differences in work attitudes. Journal of Business and Psychology, 25. 201-210. https://doi.org/10.1007/s10869-010-9165-6

Wulan, M, K., \& Ninik, F, R. (2017, February 11). Generasi Y doyan pindah-pindah kerja? [Gen Y likes to change jobs?]. Dari http://nasional.kompas.com/read/2017/02/11/17141441/ge nerasi.y.doyan.pindahpindah.kerja.simak.kompas.minggu.11.2.2017 